\title{
Analysis of New Concept English from the Perspective of Cross-cultural Communication-A Case Study in Book 2
}

\author{
Julong Wang \\ Department of English and German, Faculty of Philology, Translation and Communication, University of Valencia, \\ Spain
}

\begin{abstract}
New Concept English (NCE) is a series of English language textbooks, four volumes in total, which have gained national popularity and wide acceptance by English teachers, learners and parents in China. In the academic circle, apart from the analysis of the contents of NCE, which has been mostly discussed, many contrast studies between NCE and other English course-books are not new topics either. This paper focuses on the analysis of NCE from the perspective of cross-cultural communication and develops a detailed study on the second volume based on eight parameters: norm, value, art, custom, religion, language, ways of life, material culture. Hopefully, the current study will shed new light on NCE researches in China and arouse the attention of the academic world, because language teaching and learning is the combination of language skills and culture.
\end{abstract}

Index Terms—New Concept English, textbook, cross-cultural communication

\section{INTRODUCTION}

At the age of information explosion, when it comes to the field of English language teaching (ELT), textbooks or teaching materials we use in class have been regarded as an important element and future of a nation. Teachers rely on textbooks in selecting the contents of their lessons and the methodologies to teach the contents.

Cao (2009) has termed "the books say about themselves". Further, she remarks that what sets us against one another is not our aim - they all come to the same thing - but our methods. This can easily explain that EFL textbooks written in different countries have displayed their different methods or cultures. Hu (1997) states that our lives are closely connected with cultural influence. Culture is regarded as the keystone in each civilization and the medium of cross cultural communication.

In the history of ELT in China, we could find some English textbooks which were very influential and are very popular even nowadays. New Concept English, edited by British author of EFL course books, Louis George Alexander, first published in 1967, is especially worthwhile to talk about here, which has been exerting a prevailing influence on Chinese English language learners.

As one of the most authentic English learning materials, New Concept English has been republished quite a number of times due to its national popularity and wide acceptance by English teachers, learners and parents in China. However, most of the English training centers or autonomous learners solo focus on the vocabulary, grammar and sentence structure. Only if we truly understand the knowledge of cultural background in each lesson can we fully master the core of English language. Meanwhile, the learners can communicate with foreigners inter-culturally.

The purpose of this study is to analyze the text book New Concept English not only from the contents, most importantly, from the aspect of cross-cultural communication. Meanwhile, the author is going to show more details of cross-cultural aspects in Book 2 to help teachers, researchers and learners to achieve good understanding of such a widely used course book. The author believes that both the academic values and cultural values of the book are of great importance for all the users because it makes people fully master the target language which in turn facilitate the cross-cultural communication skills.

\section{Researches ON COURSE-BOOKS AND CULture}

Course-books play a vital role in any teaching and learning process and course-books are considered as the most basic resources in achieving teaching objectives to fulfill learners' need. Furthermore, course-books always reflect authors' beliefs concerning the nature of language and learning. At the same time, language has a close connection with culture in the sense that language teaching and learning inevitably involves the culture teaching and learning. In the following chapter, the author is going to briefly study how to evaluate one course-book and the interactions between languages and culture.

A. Studies on Foreign Language Course-books 
$\mathrm{Hu}$ regards course-book evaluation as "a matching process: matching needs to available solutions" (Hu 1997). The criteria for good textbooks can be illustrated below:

Course-books Should Correspond to Learners' Needs.

Selected course-books must help the learners attain the objectives reflecting learners' needs in terms of both language content and communicative abilities. More importantly, good course-books always facilitate the learning progress and help learners fulfill their language objects. Ultimately the content of the course-books corresponds to learners' needs in many aspects, such as key and important language points, language skills and communicative strategies.

The author has found out that some basic needs might be experienced by the language beginners when it comes to textbooks:

- the need to communicate effectively;

- the need to be familiar with the language systems;

- the need for challenges;

- the need for cross-cultural awareness.

The author gives special mention that good course-books should also have cultural knowledge of the target language, which is the meaning of this study.

\section{Course-books Should Have a Clear Role as a Support for Learning.}

Course-books, just like language teachers, may be used to mediate between the target language and the learner. Meanwhile, course-books could also facilitate learning in which they bring the learner and the target language together in a controlled way. In this sense, course-book writers could be regarded as participants in the learning-teaching process. Course-books are supposed to support the learners in the way that offering linguistic knowledge that fits students' language proficiency. Meanwhile, the scientifically-designed exercises and activities from the course-books would promote the learners' fluency in language use. Explanations or contextualized examples from course-books will help learners to better understand how the target language works.

Course-books also embody certain learning styles and strategies, which can influence how individual students go about their own learning. Learning strategies contained in the course-books might not be that explicit. Anyhow, any good course-book may include certain learning styles and learning strategies explicitly or implicitly. And it is the language teachers or course-book evaluators who must identify what they are, how they are put forward, and how they could facilitate students' language learning.

\section{B. Studies on Culture and Foreign Language Teaching}

World outlook and values have always been dealt with when we talk about cross-cultural communication.

World outlook refers to people's fundamental views on the world, including the position of people in the universe, the relationship between human and nature and so on. From the perspective of the relationship between human and nature, oriental and western cultures have completely different views. Western culture considers human beings should dominate nature. Nature is the conquest object of human. Human beings can utilize science and technology to transform nature and conquer nature. Correspondingly, oriental culture thinks human and nature have harmonious relationship. Human and nature are closely related. Human beings should not transform nature, but adapt to nature and utilize conditions of nature to serve for human being.

Value refers to the standards to judge the right and the wrong. It will guide human behaviors. So, value consists of the backbone of culture and social structure. For a person attached to a culture, their behaviors are dominated by the value. Value is an abstract concept. It is difficult for people to grasp it. But the value of a culture can be seen from linguistic or non-linguistic behavior patterns.

When it comes to foreign language teaching, we usually discuss cross-cultural communication at the same time because foreign language teaching is not only about language knowledge, but also cultivate students' communicative competence and cross-cultural communication skills as well. In this sense, it is more appropriate to regard foreign language teaching as a part of cross-cultural education. As early as the middle of 1980s, college English education in China formulated teaching program uniformly. CET-4 and CET-6 were carried out in late 1980s. All these propose higher requirements for English application ability of college students. However, universal exam-oriented education gives rise to quite large negative effects. Besides, traditional foreign language education concept also deeply constrains us. From the primary school, Chinese students have been learning English for more than 10 years. Most of their time and energy are spent in looking up words in the dictionary, remembering words and analyzing sentence pattern. They can easily deal with examinations, reading and writing, but often have many problems in cross-cultural communication.

To sum up, good textbooks should meet the learners' needs and have a clear role as a support for learning. Cross-cultural awareness is one of the fundamental needs for the foreign language learner too. In this sense, we should find out the world outlook and values from textbooks and make the learners understand the different cultures in the process of language learning.

\section{ANALYSIS OF NEW CONCEPT ENGLISH}

As a distinctive learning material, New Concept English has been popular with Chinese learners for more than forty years. Moreover, it has been used as a supplementary teaching material by a lot of teachers from the English academies 
and institutes. In the following sections, the author is going to analyze NCE from the aspect of academic function and its cross-cultural value.

\section{A. Academic Values of New Concept English}

1. Contents and Topics

Book One First Things First is an integrated course for beginners. It is divided into 3 parts: lesson 1-72; page 1-72 are the basic sentence patterns in British people's daily life. After that there is a test. There are situational conversations from Lesson 73 to Lesson144. Series of cartoon pictures display the daily life of the British people. This book involves the common topics such as transportation; clothing; schooling; buying, etc.

Book Two Practice and Progress is an integrated course for pre-intermediate students including ninety six lessons. There are four units (twenty-four lessons in each) in the book. Four pre-unit texts are designed as searching tests, in which students are able to find out their own level to start learning at any point of the book. The passages in each lesson become longer and more complex from the first unit to the last. New words and expressions are listed below the passages, followed by notes on the text and Chinese translations. Students are required to do exercises on the book to drill the key sentence structures and the difficult points. In the end of each lesson, 12 multiple choice questions are given to test learners' text comprehension competence, key sentence structure knowledge and important vocabulary.

Book Three Developing Skills is an integrated course for intermediate students. It is said that the materials in Practice and Progress, the pre-intermediate course which precedes this one, have been designed to 'overlap' this course (Sun 2008). This book includes sixty lessons.

The forty-eight articles in Book Four Fluency in English, are extracted from many prestigious publications. For instance, the eighth lesson Trading Standards is selected from The Economist; the tenth lesson Silicon Valley is from US News and World Report. The far more complicated vocabulary and sentence structures in this book often make students stunned and lose their courage to challenge themselves, because the language skills in the first three volumes of NCE would satisfy most learners' needs.

2. Skills and Methodology

The passages are texts with multi-purposes. Each passage will be used to train the students' multiple skills: aural comprehension; oral practice (progressive and static patterns); oral composition; dictation and composition practice (simple, compound and complex sentences), so on and so forth.

It is obvious that the NCE textbooks employ the contemporary theories of linguistics and English methodologies: the grammatical syllabuses, the situational approach and the audio-lingual method. It goes through these methods using the tapes and the new structural patterns are presented in dialogues with visual "cartoon strips", which create a vivid situation for English teaching and learning.

It needs to point out that the audio-lingual method is the fundamental methodology to fulfill the target language learning. As claimed by Alexander in the introduction of NCE, it is based on these principles. 1. Sentences are seen as units for learning and using; 2. Words are classified in two categories: structural and lexical; 3. Structural words decide the meaning and hold sentences together; 4. Mistakes should be prevented from the very beginning, and correct habit of language use should be formed; 5. Structures should be taught to the students with increasing difficulty. These principles are typical of structuralism approach, so we label NCE with "structural-situational".

Indeed, it is a great progress from the traditional grammar-translation approach, which views language as a set of prescriptive rules to be memorized. By giving students chances to encounter spoken language, NCE enables students to develop aural/oral skills in using the language. It is an "innovation" in reaction against the traditional grammar-translation approach. As noted by most linguists that the structuralism initiated a new era in language acquisition and education, both theoretically and practically. This new era of language pedagogy signified with scientific theories as pedagogical guidelines. From then on, researches of linguistic theories and its implication for teaching flourished. In this sense, NCE, together with other audio-lingual structuralism textbooks is a great contribution to mankind in the development of intercultural exchanges. So far as China is concerned, millions upon millions of people of various age groups and of opposite sexes, who take a fancy to learning English resort to NCE. To some extent, NCE play a part in the improvement of English level in different parts of China.

\section{B. Intercultural Values of New Concept English}

Apart from the academic values discussed in the previous section, the author is going to reveal the intercultural values of NCE from three perspectives.

1. Perception

Perception is defined by David (2001) as "the internal process by which we select, organize and interpret information" from the outside world. Our perceptions are culturally determined and in turn influence the way we communicate with others.

From NCE we can understand how the westerners perceive the life and world. For instance, Book 1 is mainly about some real life descriptions and conversations. But jus from such simple background can we know what is the kitchen like (Lesson 15), what is the living room like (Lesson 27), how they go shopping (Lesson 79). For most British families, the most important domestic appliances are fridge and oven. Normally they go to the market on weekends with family members and get what they need for the next whole week. That's why a shopping list is quite useful for them because 
shopping list is the best reminder. They will place all the food and drink into the fridge. Oven is used to make cake or roast meat. Meanwhile, the illustrations in each lesson from Book 1 provide the learners huge cultural information from which we can easily figure out people's perception toward the life and the world.

2. Values

Values are defined by Jandt (2001) as "an enduring set of beliefs that serve to guide or direct our behavior". Values always represent the norms of a culture and specify the standard of being good and bad, right and wrong, rude and polite, appropriate and inappropriate, so on and so forth.

From Book 2, western values start to emerge. Top one value of the British identity is the rule of law. The narrator in Lesson 21 refused the large sum of money from the local authority to move his house close to the airport. The law protects his personal property. The narrator in Lesson One was angry at the theater because a young man and a young woman who sit behind him were talking so loudly that the narrator could not hear one single word from the actors. The Swedish traffic police's polite note on the car made the narrator in Lesson 16 shameful to break the local traffic rules. All the examples above have shown that the society is always based on the same rules. No matter who you are, you have to obey these rules and every citizen shares the common value.

3. Beliefs

According to Samovar (1997), beliefs are said to be the judgments we make about what is true or false. Moreover, beliefs are usually linked to certain tangible objects with certain features that we believe to be true with. In this sense, beliefs are rooted in the heart and can be influenced by people surround you and by the society you are living in.

For instance, most people in the west believe never too old to learn. They don't stop learning even after retirement. In Book 2, the retired teacher from Lesson 85 started to learn gardening, which could set a good example for our young learners. The New Year Resolutions from Book 3 told us that even if we often do not fulfill our New Year Resolutions, it is also believed to be an important occasion. One Man in a Boat told us to ignore people's general comments and to follow what you would like to do. If you enjoy the process of fishing, it is not important how many fish you have caught.

\section{Summary}

To conclude, following the criteria of textbook evaluation, on the academic perspective, NCE is compiled under a complete and scientific system, in which learners are able to fully develop their primary skills of reading comprehension, listening, writing and spoken English. Besides, NCE is a valuable teaching material for studying western culture. The learners can also foster cross-cultural communicative skills in the process of the target language study.

In the following chapter, the author is going to study NCE Book 2 in detail from the perspective of cross-cultural communication.

\section{A Case Study of New Concept ENGLish Book Two}

Book Two of NCE, Practice \& Progress, aims to provide a comprehensive course for post-elementary adults or students in secondary education who have already acquired certain English vocabulary and basic grammar. In this respect, suitable materials have been designed to make learners continue practicing oral English, passage writing, more complicated sentence structure and more advanced grammar. However, in this chapter, the author is going to highlight the cultural background of this book to arouse the attention of the users of NCE Book Two.

\section{A. Research Parameters}

Culture could be defined as the symbols, language, beliefs, values, and artifacts that are part of any society ${ }^{1}$. According to this definition, two basic components of culture could be inferred: nonmaterial culture and material culture. The former type includes the values, beliefs, symbols, norms, religion, language, art, customs and tradition, ways of life that could define a society; the latter one could refer to all the physical objects in a particular society, such as technology, clothing that people are wearing, and tools of communication, so on and so forth.

The ninety six texts from NCE Book Two were analyzed based on the following parameters: norm, value, art, custom, religion, language, ways of life, material culture. Even if material culture is so general a category, from the author's perspective, there is still a need to treat material culture as an independent parameter because the civilized objects talked in Book 2 are various. It makes little sense to separate each object.

\section{B. Results and Discussion}

Based on the parameters I chose above, an overview of the results shows that all the ninety-eight passages in NCE Book Two share the common features listed below:

- Western ways of life are often introduced.

- Industrial revolution has greatly influenced British society.

- Norms of the society characterized individualism.

\footnotetext{
${ }^{1}$ Reference from a webpage. The Elements of Culture. 〈http://open.lib.umn.edu/sociology/chapter/3-2-the-elements-of-culture/>. Sociology: understanding and changing the social world. Libraries Publishing.
} 
- Be adventurous is one of the most mentioned values.

- Play and film watching are important forms of art.

- Black humor is deeply rooted in British culture.

In the following passages, I will discuss these features in greater depth. It has to be mentioned that, some passages could be categorized into more than one parameter I have just mentioned.

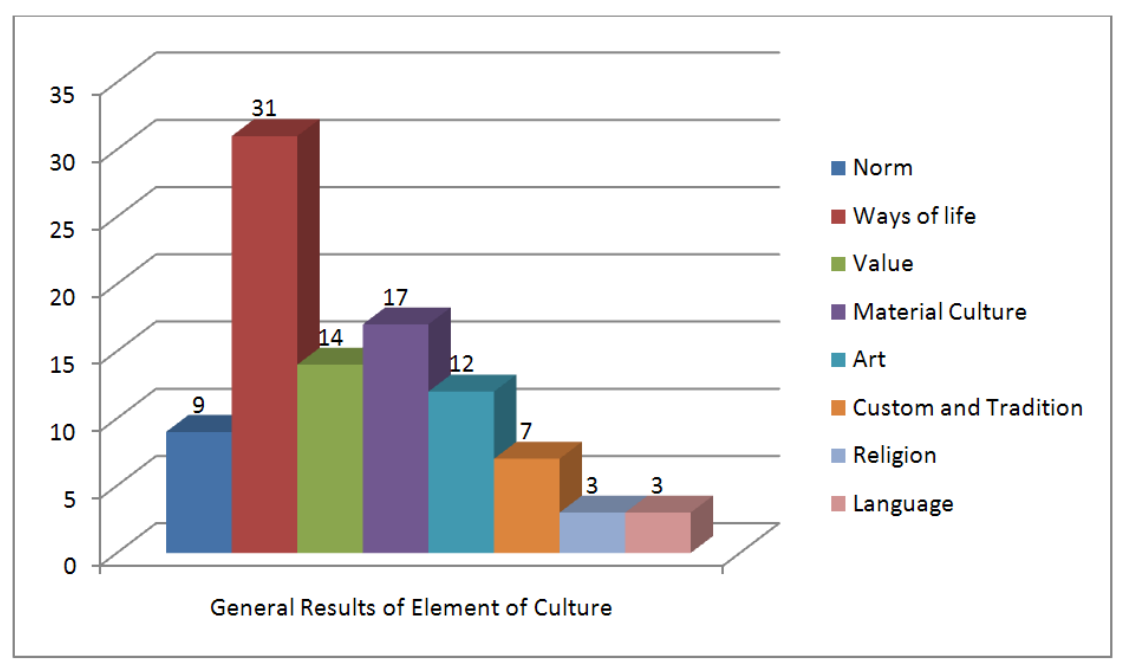

As is the figure shown above, ways of life (31 lessons) is mostly talked about in this textbook, which accounts for $32 \%$, followed by material culture $(17 \%)$, values $(15 \%)$ and art (13\%). Norms, customs and traditions are mentioned with a small quantity, while the number of texts of religions and languages are equal and scarcely displayed.

Norm

According to Cliffs Notes $^{2}$, norms are the agreed upon expectations and rules by which a culture guides the behavior of its members in any given situation. Of course, norms vary widely across cultural groups. British people, for instance, maintain fairly direct eye contact when conversing with others. Asians, like Chinese, on the other hand, may avert their eyes as a sign of politeness and respect.

In Lesson 40 Food and Talk, the narrator went to dinner party. He was asked by the hostess to sit next to a large, unsmiling lady. Supposedly, the lady was one guest of the hostess. In western culture, especially at a dinner or wedding party, all the guests must follow the hostess's arrangement. One of the reasons is that the number of the guests is always fixed. You couldn't attend the party without an invitation. Therefore, according to the norms of a party, the hostess often arranges the seats for each guest before he arrives. Also, a name card can often be found on the table.

However, we Chinese may find it strange or offensive. It seems that "The more, the merrier" is considered as the norm of Chinese society. People invited or even not invited will be welcome. The hostess always prepares more food and drink just in case more guests show up at the party, because some people may not be present that day while someone may bring his/her family members. Furthermore, the invited guests may feel free to choose their seats.

\section{Ways of life}

There are quite a number of ways in which Europeans are just better at life. Across the pond, larger cities flaunt extensive metros and buses circumnavigate nearly every town. Westerners love travelling in the bus or train to escape the noise in the big cities to enjoy the countryside. In many European nations, citizens get around 30 paid days off per year, not to mention the two-day weekends. Nobody criticizes them for being lazy.

In Book Two, we can find the following typical British ways of life: getting up late in weekends, gardening, drinking in the pub, boat fishing, camping, excursion, party, pets and car race.

For example, in Lesson 8 The Best and the Worst, "The Nicest Garden Competition" was held each year. The first prize and the last competitor will be rewarded. It needs to be mentioned that British people who live out of the city or countryside, usually have gardens in their house. Different from most Chinese house gardens which are fenced in the walls, most gardens in UK are visible. Apart from garden competition, we can also find the description of garden in Lesson 23, 28, 59.

Car race has been talked about in Lesson 56 and Lesson 72. People were even amused by an old car race, where the drivers spent more time fixing the car in the race than driving in the car. It's a way to enjoy the life and the result has always been ignored.

On the other hand, Chinese have been considered as one of the most hardworking people in the world, and a large number of people seldom spend holidays and they work even on weekends. When we make friends with the westerners, it's important to know that no one of them wants to be disturbed on weekends or in their holiday.

\footnotetext{
2 From a webpage. Cultural Norms. <https://www.cliffsnotes.com/study-guides/sociology/culture-and-societies/cultural-norms >. Cliff Notes. Houghton Mifflin Harcourt.
} 


\section{Value}

As we have discussed in the previous chapter, the study of values here is to about how Europeans think about family, work, religion, politics and society, so on and so forth. Collectivism can often be found in Chinese communities because they prefer to live group. It has been hundreds of years when the married couples live with their parents, or even grandparents. However, the westerners are just the opposite.

Lesson 1 A Private Conversation can fully demonstrate how the British value the privacy. Even though the text ends with a humor, it can also be viewed as a good example. We were taught that topics like salary, marriage are so private that it is offensive to ask the westerners when we first meet. Apart from that, the place people live is also private. The flat mate, even the parents cannot enter the door of your room without permission, which is essential to mention when we share one flat abroad.

Another point we found is that the westerners value adventurousness, which is shown in Lesson 12, 29, 33, 36, 43, and Lesson 67: boat sailing race across the Atlantic, driving an airplane as a taxi, swimming across the English Channel, flying over the South Pole, observing active volcanoes, where the Chinese learners may find it exotic and crazy. Only if we understand what the westerners' value can we communicate with them and respect their adventurous hobbies.

\section{Material Culture}

The author examines the intellectual foundations of consumerism in food, dress, shelter, utilities, and information from Book 2. Adshead (1997) states that "material culture highlights consumerism as an expression of both rationality and freedom and indicates the constructive role it has played in the formation of the modern world".

Material culture refers to tools, artifacts and technology. We can find the European tableware in Lesson 11; the traditional lady's tall hat in Lesson 41; the local food --- butter, meat pies in Lesson 54 and world famous British fish and chips in Lesson 90; the London's landmark --- Big Ben in Lesson 71 etc. The learners need to know how do the British use knife and forks, how to drink wine and coffee, the table manner, the varieties of coffee (black coffee, coffee with milk, coffee with ice etc.), the traditional and royal clothes, their eating habits, together with the popular landmarks in each country.

In particular, learns need to know how to invite friends for dinner or a drink because it is at that moment where intercultural communication happens. Normally, Europeans go Dutch when get together with friends. They order their own dishes and pay separate bills while the Chinese tend to share what they order at a restaurant and usually the man is the bill payer when he dates with ladies.

Art

As explained by UNESCO, the performing arts range from music, dance and theatre, etc. Arts can be quite a number of cultural expressions that reflect human creativity and, to some extent, arts can also be found "in many other intangible cultural heritage domains" ${ }^{3}$.

As one important performing art, Jazz is mentioned in Lesson 10 and Lesson 42. Many jazz bars and pubs can be found in the west. At the same time, pop music is welcome by younger listeners. The Greenwood Boys are a group of pop singers and they have been performing all around the country.

As we all know, Shakespeare is the most important writer in UK. Plays were also born in UK and theaters are quite common in Europe. This kind of art can be found in Lesson 1, 17 and Lesson 19. Students in the west were encouraged to perform on the school stage at festival time and most importantly, at graduation ceremony. The price to pay at a theater is normally higher than a ticket in a cinema, because such creative performance has been paid more attention. The Chinese learners need to know the manners to go to the theater, for example, silent the smart phones, no flash when the actors/actresses are playing on the stage.

\section{Custom and Tradition}

UK is where authentic English culture takes shape. Since English is taken as a global language, a lingua-franca, British customs and traditions have spread many parts of the world and have influenced all the English-spoken areas. The typical English customs and traditions may be drinking tea, eating fish and walking in the street with an umbrella.

In Lesson 9, we can find out people get together at the city hall before 12 on December 31 to celebrate the coming New Year. People wait for the clock to strike twelve times and dance and sing. In some countries, like Spain, after dinner, family member will eat twelve grapes each time the clock strikes. This is said to bring luck for the coming New Year.

Festivals like April Fools' Day and Christmas in the west, Festival for the Dead in Japan are also shown in the Book 2. At Christmas time, apart from the common knowledge that the kids receive the gifts from their parents, the kids are also taught to send gifts to the social organizations and to the people in need. Normally friends don't exchange presents at Christmas. On April 1, you can joke with your friends before 12 o'clock. No serious joke can be talked after lunch if you want to be a fool.

All the western customs and traditions should be clear to the learners if they would like a successful intercultural communication.

\section{Religion}

Religion always offers the best insight into a society's behavior and usually helps answer the question why people are

\footnotetext{
${ }^{3}$ Reference from a webpage. Performing arts (such as traditional music, dance and theatre). <https://ich.unesco.org/en/performing-arts-00054>. UNESCO.
} 
behaving in that way, rather than how they should behave themselves not to look so odd ${ }^{4}$.

Religious holidays like Christmas and churches have been mentioned in Book 2 as well. Superstitious western people relatively believe the crystal ball to foretell their fortune (Lesson 60). Anyone touches the "cursed tress" will have bad luck (Lesson 58). Some believe the ancient Greek myths, as we can see in Lesson 28.

Learners should bear in mind some tips when they visit a church. First no slippers are allowed to enter the church. Mute the smart phones. Pride, envy, gluttony, lust, anger, greed, sloth are regarded as seven deadly sins.

\section{Language}

According to Carter (1997: 68), "language reflects the nature and values of society. There may be many sub-cultural languages like dialects which may have to be accounted for". Accent is also part of languages. People from different areas may have different accents. We have no difficulty understanding this if we think about our own various accents and dialects.

In Lesson 25, the narrator found difficulty understanding the British English when he arrived in UK because the local accent was quite different from what he had learnt in his country. The Chinese learners with high scores of English might have the same problems when they travel to London for the first time. From the author's perspective, the major reason lies in the fact that the second language our learners perceive in China is standardized English, academic English, so to speak. The British might find a bit strange when they communicate with us.

Another reason might be that there are lots of dialects in Britain. The only way to overcome is to strengthen the learners' listening skills. Prepare different listening materials from real life situation.

\section{Summary}

In this chapter, the author conducted a detailed study on the second volume of NCE based on eight parameters: norm, value, art, custom, religion, language, ways of life and material culture. Under each parameter, the author illustrated samples from the book to distinguish each category. Meanwhile, the author highlighted the key points to pay special attention in the process of cross-cultural communication.

However, there are some texts in Book 2 which can be labeled as more than one category because of various cultural elements. For instance, we can not only analyze the first lesson A Private Conversation from the perspective of value, but from the perspective of art as well. Therefore, the percentage of each cultural element is not fixed and may differ, which is the limitation of the case study

\section{CONCLUSIONS}

To repeat, a textbook is the core teaching material of a curriculum and embodies the view of the curriculum, the view of linguistics and the view of language acquisition or learning. New Concept English provides a set of excellent learning materials and is well received by the field of English education in China.

From the above analysis, it can be concluded that generally the academic contents in the books are in accordance with the linguistic theories. And the study can provide references to the English teachers in and out of China. When emphasizing the study of communicative skills, the teacher should also take the cross-cultural communication into consideration and help to improve the cross-cultural communicative competence of the learners. And the study suggests that the editors of English textbooks should combine the contents and culture and keep the languages alive to make the learners to fulfill the ultimate target of foreign languages learning, that is to say, to communicate with foreigners fluently and to think in their shoes.

Furthermore, NCE features thematic teaching and focuses on the language learners. Students become the center in English study, thus they are more eager to learn. And NCE emphasizes the combination of listening and speaking and thus fosters the students' communicative competence, which is breakthrough of the traditional English teaching. And the topics are new and interesting and can therefore be attractive to the students.

\section{REFERENCES}

[1] Adshead, S.A.M. (1997). Material Culture in Europe and China, 1400-1800. Basingstoke: Palgrave Macmillan UK.

[2] Alexander, L. G. \& He, Q. X. (1997). New Concept English. Beijing: Foreign Language Teaching and Research Press.

[3] Backlund, P. (1978). Defining Communication Competence. Annandale: Communication Education.

[4] Brislin, R. \& Yoshida, T. (1994). Intercultural Communication Training: An Introduction. Thousand Oaks: Sage.

[5] Carter, S. (1997). Global Agricultural Marketing Management. Food \& Agriculture Org.

[6] Davis, L. (2001). Doing Culture: Cross-cultural Communication Action. Beijing: Foreign Language Teaching and Research Press.

[7] Food and Agriculture Organization of the United Nations. The Cultural Environment.

[8] http://www.fao.org/docrep/W5973E/w5973e07.htm.

[9] Gudykunst, W. B. (1983). Intercultural Communication Theory: Current Perspectives. Berverly Hills: Sage. Houghton Mifflin Harcourt. Cultural Norms. 〈https://www.cliffsnotes.com/study-guides/sociology/culture-and-societies/cultural-norms>.

[10] Hu, W. Z. (1997). Foreign Language Teaching and Culture. Changsha: Hunan Education Press.

\footnotetext{
${ }^{4}$ Reference from a webpage. The Cultural Environment. 〈http://www.fao.org/docrep/W5973E/w5973e07.htm>. Food and Agriculture Organization of the United Nations.
} 
[11] Jandt, F. E. (2001). Intercultural Communication: An Introduction (third ed.). Thousand Oaks: Sage.

[12] Jia, Y. X. (1997). Intercultural Communication. Shanghai: Shanghai Foreign Language Education Press.

[13] Li, J. N. (2007). New Concepts of New Concept English. Master Dissertation, Harbin University of Science and Technology.

[14] Lin, D. J. (1996). Intercultural Communication Studies. Fuzhou: Fujian People's Publication House.

[15] Libraries Publishing. The Elements of Culture. <http://open.lib.umn.edu/sociology/chapter/3-2-the-elements-of-culture/>.

[16] Long, X. (2009). New Concept English: Advantages and Disadvantages. Education and Teaching Research 5, 8-10.

[17] Samovar, L. A. (1997). Intercultural Communication: A reader (eighth ed.). Belmont: Wadsworth Publishing Company.

[18] Sun, W. Q. (2008). A Comparison of English by Xu Guozhang VS New Concept English. Master Dissertation, Shanghai Normal University.

[19] UNESCO. Performing arts. <https://ich.unesco.org/en/performing-arts-00054>.

[20] Xu, L. S. (2000). Analysis on Intercultural Communicative Competence. Foreign Languages and Their Teaching 7, 45-49.

[21] Zhan, S. X. \& Li, H. (2006). A Brief Analysis of New Concept English: $2^{\text {nd }}$ volume. Journal of Taiyuan Urban Vocational College 5, 125-126.

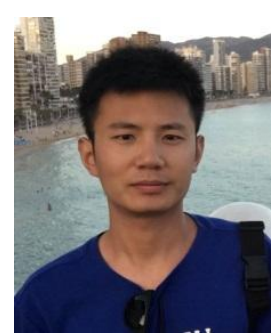

Julong Wang, born in China, is doing his doctoral program of Languages, Literatures, Cultures and Applications in Faculty of Philology, Translation and Communication, University of Valencia, Spain. The author's major field of study is Teaching English as a Foreign Language.

He has been working as an English instructor and researcher for more than 10 years in China and in Spain. He delivered his talk on "The Authenticity of Real Texts in Advanced English Language Textbooks from Chinese Universities: Final Results" at IV Conference Innovation in Valencia in 2016. At the same year, Mr. Wang attended TeCola Project which was funded by European Union. 